Economics Development Abalysis Journal 7(3)(2018)

\title{
Pengaruh Pinjaman Daerah, Pendapatan Asli Daerah Terhadap Kemiskinan Dan Pertumbuhan Ekonomi Di Jawa Tengah
}

\author{
Atika Nur Oktaviani ${ }^{凶}$
}

Jurusan Ekonomi Pembangunan, Fakultas Ekonomi, Universitas Negeri Semarang

\begin{tabular}{l} 
Info Artikel \\
\hline Sejarah Artikel: \\
Diterima April 2018 \\
Disetujui Juni 2018 \\
Dipublikasikan Agustus \\
2018 \\
\hline Local Govermenst \\
Borrowing, Locally- \\
Generated Revenue, Poverty, \\
Economic Growth, Panel \\
Data \\
\hline
\end{tabular}

\begin{abstract}
Abstrak
Penyelenggaraan otonomi daerah memiliki tujuan untuk meningkatkan kesejahteraan masyarakat. Anggaran pinjaman daerah yang dilakukan pemerintah daerah sebagai upaya pembangunan fasilitas publik untuk mobilitas ekonomi masyarakat daerah sehingga dapat meningkatkan pertumbuhan ekonomi daerah. Tetapi peningkatan pertumbuhan ekonomi tidak sesuai dengan pergerakan penurunan kemiskinan. Hal ini berakibat terhadap perekonomian daerah. Oleh karena itu, perlu mengetahui pengaruh pinjaman daerah, pendapatan asli daerah terhadap kemiskinan dan pertumbuhan ekonomi daerah $21 \mathrm{kab} /$ kota di Jawa Tengah. Variabel penelitian ini yaitu pinjaman daerah dan pendapatan asli daerah sebagai variabel independen, Kemiskinan dan pertumbuhan ekonomi sebagai variabel dependen. Jenis penelitian ini adalah kuantitatif dengan menggunakan analisis data panel. Hasil penelitian menunjukkan bahwa terdapat pengaruh antara pinjaman daerah terhadap kemiskinan. Terdapat pengaruh antara pendapatan asli daerah daerah terhadap kemiskinan. Terdapat pengaruh antara pinjaman daerah terhadap pertumbuhan ekonomi. Tidak terdapat pengaruh antara pinjaman daerah terhadap pertumbuhan ekonomi..
\end{abstract}

\begin{abstract}
The implementation of regional economy aims to improve public welfare. Local government budgethadbylocal government is as an effort of public facility developments for economic mobility of regional society so that it is able to increase regional economic growth. However, the increasing of economic growth is notinaccordancewith the movement of poverty reduction. It has several impacts to regional economy. Therefore, it needs to knowthe influence of local government borrowing toward locally-generated revenue, poverty, and regional economic growth $21 \mathrm{kab} / \mathrm{kota}$ in Central Java. The research of variable local goverment borrowing and locally-generated revenue, poverty and economic growth as the dependent variable. Type of this research is quantitativeusingpanel data analysis. The results showed that there is influence local goverment borrowing toward poverty. Thereisthe influence of locally-generated revenue toward poverty. There is influence local goverment borrowing toward economic growth. There is no locally-generated revenue toward economic growth..
\end{abstract}




\section{PENDAHULUAN}

Negara Republik Indonesia telah mengalami beberapa perubahan dalam hal hubungan keuangan dan pembagian tugas antara pemerintah pusat dan daerah. Pada masa orde baru, hubungan keuangan antara pemerintah pusat dan daerah diatur berdasarkan UU Nomor 5 Tahun 1974. Selanjutnya undang-undang tersebut membuat peranan dan potensi pemerintah daerah untuk dapat berkembang semakin terbatasi. Kebijakan keuangan yang diterapkan terlalu menguntungkan pemerintah pusat. Sumber-sumber potensial di daerah yang mampu mendatangkan penghasilan telah diambil oleh pemerintah pusat sebagai sumber penerimaan. Sehingga yang tersisa di daerah hanya sumber-sumber yang kurang potensial. Hal ini menyebabkan pemerintah daerah memiliki ketergantungan cukup tinggi terhadap transfer dari pusat.

Dengan bergulirnya era reformasi, pembangunan berpola konglomerasi selama kepemimpinan orde baru mulai digantikan dengan pembangunan berpola ekonomi rakyat. Penerapan pembangunan yang berpola ekonomi rakyat dicerminkan melalui pemberlakuan otonomi daerah. Pemerintah pusat memberikan wewenang kepada pemerintah daerah untuk dapat mengatur rumah tanggannya sendiri. Pemerintah daerah diselenggarakan sebagai sub sintem pemerintahan negara yang dimaksudkan untuk meningkatkan efektifitas dan efisiensi penyelenggaraan pemerintahan. Hal ini diatur dalam UU Nomor 32 Tahun 2004 tentang pemerintahan daerah dan UU Nomor 33 Tahun 2004 tentang perimbangan keuangan pusat dan daerah. Daerah otonom mempunyai wewenang dan tanggungjawab terhadap kepentingan masyarakat berdasakan prinsip-prinsip keterbukaan dan partisipasi masyarakat.

Penelitian (Ariwibawa, 2005:21-22) bahwa Pemerintah Kota Semarang melaksanaan kegiatan pemerintahan dan pembangunan, selain menggunakan sumber-sumber penerimaan daerah yang dimiliki juga telah memanfaatkan dana pinjaman sebagai sumber pembiayaan.
Pinjaman pemerintah daerah Kota Semarang sebagian besar bersumber dari luar negeri dan lembaga bank, yaitu dari Bank Dunia dan Bank Jawa Tengah. Pinjaman ini dipergunakan untuk pembangunan perkotaan yang meliputi antara lain jalan perkotaan, air bersih, drainase, air limbah, persampahan, perbaikan kampung, dan pasar.

Hal itu untuk menuju pada kemandirian daerah dalam membiayai pengeluarannya, pemerintah daerah berupaya keras untuk meningkatkan pendapatan asli daerahnya sebagai sumber pendanaan. Selain PAD perlu adanya alternatif sumber pembiayaan untuk pembangunan perkotaan. Pinjaman daerah dapat menjadi salah satu alternatif pembiayaan pembangunan perkotaan. Untuk menindaklanjuti hal tersebut pemerintah telah mengeluarkan Peraturan Pemerintah RI Nomor: 107 Tahun 2000 tentang Pinjaman Daerah. Terdapat berbagai sumber pinjaman yang diterapkan diberbagai negara, antara lain berasal dari pemerintah pusat, pasar modal, lembaga kredit, lembaga bank/bukan bank, dan luar negeri (LPEM-UI, 2004:4-5).

Pinjaman daerah yang nantinya akan menghasilkan pendapatan bagi daerah tersebut berupa pendapatan asli daerah. Oleh sebab itu pendapatan asli daerah yang tinggi akan meningkatkan fasilitas daerah. Pendapatan daerah yaitu penerimaan yang sangat penting bagi pemerintah daerah dalam menunjang pembangunan daerah guna membiayai proyekproyek dan kegiatan daerah. Fungsi pendapatan daerah dilihat dari fungsi alokasi dipergunakan untuk barang privat dan barang publik dimana keduanya sangat dibutuhkan oleh masyarakat. Dalam rangka penyelenggaraan otonomi daerah, penyerahan, pelimpahan dan penugasan urusan pemerintah kepada daerah secara nyata dan bertanggungjawab harus diikuti dengan peraturan, pembagian, dan pemanfaatan sumber daya nasional secara adil, termasuk pembagian kewenangan dalam pengelolaan keuangan negara dan perimbangan keuangan antara pemerintah pusat dan pemerintah daerah. 
Tabel 1. Pinjaman Daerah 21 Kabupaten /kota di Jawa Tengah Tahun 2010-2015 (Juta)

\begin{tabular}{lllllll}
\hline Kab/kota & 2010 & 2011 & 2012 & 2013 & 2014 & 2015 \\
\hline Brebes & 2.000 & 2.500 & 2.500 & 2.500 & 2.750 & 2.900 \\
Pemalang & 3.500 & 3.500 & 3.500 & 3.500 & 3.500 & 3.500 \\
Batang & 2.000 & 13.450 & 2.500 & 2.500 & 2.750 & 1.805 \\
Kendal & 3.000 & 3.000 & 2.000 & 1.666 & 1.166 & 666 \\
Semarang & 2.500 & 3.000 & 3.500 & 4.000 & 4.500 & 5.000 \\
Jepara & 2.400 & 2.400 & 1.600 & 1.333 & 933 & 533 \\
Pati & 1.600 & 1.600 & 1.600 & 1.600 & 1.600 & 1.600 \\
Rembang & 1.500 & 1.500 & 1.500 & 1.500 & 1.500 & 1.500 \\
Sragen & 1.600 & 1.800 & 14.915 & 11.515 & 18.172 & 22.818 \\
Banjarnegara & 1.250 & 2.500 & 3.750 & 5.000 & 6.250 & 7.500 \\
Banyumas & 2.500 & 2.500 & 2.500 & 2.500 & 2.500 & 2.500 \\
Blora & 2.039 & 2.238 & 2.438 & 1.601 & 4.911 & 2.000 \\
Boyolali & 3.000 & 3.000 & 3.000 & 211 & 88 & 35 \\
Grobogan & 3.677 & 46.725 & 10.486 & 4.846 & 8.250 & 4.977 \\
Kebumen & 3.250 & 3.500 & 3.750 & 4.000 & 4.250 & 4.500 \\
Purbalingga & 2.100 & 2.100 & 2.100 & 2.100 & 2.100 & 2.100 \\
Purworejo & 2.250 & 3.000 & 3.750 & 4.500 & 5.250 & 6.000 \\
Sukoharjo & 2.500 & 3.000 & 3.500 & 4.000 & 4.500 & 5.000 \\
Temanggung & 198.776 & 168.207 & 137.638 & 107.069 & 76.500 & 45.931 \\
Kota magelang & 175 & 285 & 395 & 505 & 220 & 220 \\
Kota surakarta & 826 & 41.000 & 32.441 & 4.000 & 19.807 & 19.903 \\
\hline
\end{tabular}

Sumber: Dirjen Perimbangan Keuangan Daerah diolah, 2017

Pinjaman daerah yang dilakukan oleh 21 kab/kota di Jawa Tengah tujuannya untuk mempercepat proses pembangunan di daerah serta meningkatkan kualitas pelayanan publik terutama di bidang infrastruktur maka pemerintah membuka kesempatan kepada pemerintah daerah untuk melakukan pinjaman sebagai salah satu sumber pembiayaan pembangunan. Akan tetapi sampai saat ini, pinjaman dari pemerintah pusat tersebut belum menjadi instrumen umum bagi daerah untuk menutup defisitnya dan/atau membiayai pembangunan infrastruktur serta peningkatan kualitas pelayanan publik. Salah satu alasan yang mungkin mengurangi minat pemerintah daerah untuk meminjam dari pusat adalah masih relatif mahalnya bunga yang harus dibayarkan. Hal ini mungkin akan menjadi sangat berarti khususnya bagi pemerintah daerah yang memiliki keterbatasan anggaran maupun sumber-sumber penerimaan daerah.

Terpenuhi fasilitas daerah akan memacu peningkatan pertumbuhan ekonomi. Menurut
Mulyono (2007:28), bahwa pertumbuhan ekonomi yang lebih tinggi akan mengakibatkan pada pemenuhan demand yang tinggi untuk layanan kota, pemerintah harus meningkatkan infrastruktur ekonomi dan pelayanan publik yang lebih baik dan kondisi ini akan berdampak pada tingginya pengeluaran daerah, untuk menutupi kekurangan dana maka pemerintah daerah melakukan pinjaman. Sehingga jika pinjaman daerah meningkat atau bertambah maka pertumbuhan ekonominya meningkat.

Menurut Santosa (2013:131), peningkatan kemiskinan disebabkan oleh meningkatnya pendapatan yang tidak diikuti dengan meningkatnya pertumbuhan ekonomi. Peran investasi di Jawa Tengah sangat besar dalam menumbuhkan perekonomian di daerah karena multiplier effect dari investasi akan meningkatkan produktivitas, memicu pertumbuhan dan berpeluang meningkatkan pendapatan masyarakat dan mengurangi kemiskinan. Investasi yang tinggi dapat menjadi pendorong roda perekonomian daerah dan 
meningkatkan kesejahteraan masyarakat ketika semua pihak mendapat manfaat maksimal dari aktivitas tersebut. Investasi adalah komitmen atas sejumlah dana atau sumber daya lainnya yang dilakukan pada saat ini dengan tujuan memperoleh sejumlah keuntungan dimasa yang akan datang.

Menurut Mulyono (2007:35), menyatakan akibat dari tingginya kepemilikan sumber daya akan berdampak adanya surplus anggaran, dengan demikian akan meningkatkan beban utang karena terdapat ketersediaan dana yang cukup untuk membayar utang. Maka dapat disimpulkan semakin besar pendapatan asli daerah, maka semakin besar pinjaman daerah yang dilakukan pemerintah daerah.

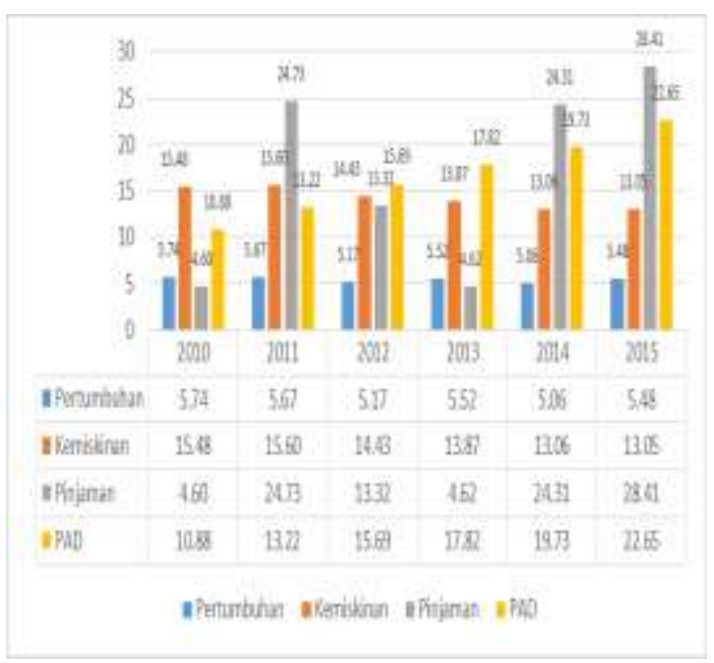

Gambar 1.. Rata-rata Pinjaman Daerah, PAD, Pertumbuhan Ekonomi dan Kemiskinan kab/kota di Jawa Tengah Tahun 2010-2015 Sumber: BPS, DPPKAD, diolah 2017

Berdasarkan gambar 1.2 bahwa pinjaman daerah 2010-2015 yang dilakukan kab/kota di Jawa Tengah tidak selalu meningkatkan pendapatan asli daerah, pertumbuhan ekonomi, dan menurunkan angka kemiskinan. Pada kenyataannya pinjaman daerah pada tahun 2010 mengalami kenaikan dari 4,60 persen menjadi 24,73 persen dapat meningkatkan pendapatan asli daerah dari 10,88 persen menjadi 13,22 persen tetetapi pertumbuhan ekonominya mengalami penurunan dari 5,74 persen menjadi 5,67 persen. Padahal menurut (Iskandar
Simorangkir :2016) pemerintah daerah mengalokasikan pinjaman daerah dan obligasi daerah untuk pembangunan infrastruktur karena dengan infrastruktur dapat meningkatkan konektivitas antar wilayah dan pengembangan ekonomi daerah yang pada akhirnya meningkatkan pertumbuhan ekonomi, dari dana pinjaman daerah tersebut juga untuk pengoptimalan potensi daerah, mekanisme pengelolaan keuangan daerah dan pengelolaan aset daerah untuk meningkatkan pendapatan asli daerah.

Latarbelakang yang telah dipaparkan diatas menjadi dasar ketertarikan dilakukan penelitian ini untuk mengetahui pengaruh antara pinjaman daerah, pendapatan asli daerah terhadap kemiskinan dan pertumbuhan ekonomi.

\section{METODE PENELITIAN}

Jenis data yang digunakan dalam penelitian ini adalah data sekunder yang diperoleh dari Dirjen Perimbangan Keungan Departemen Keuangan Republik Indonesia. Data yang digunakan adalah data panel. Data panel adalah data yang merupakan gabungan dari data time series dengan data cross section. Variabel penelitian yaitu pinjaman daerah, pendapatan asli daerah, kemiskinan dan pertumbuhan ekonomi.

Penelitian ini menggunakan metode analisis deskriptif kuantitatif dan analisis data panel. Menurut Agus Widarjono (2009) disebutkan bahwa ada tiga teknik yang biasa digunakan untuk mengestimasi model regresi data panel yaitu pendekatan Common Effect, pendekatan efek tetap (Fixed Effect Model), dan pendekatan efek acak (Random Effect Model)

\section{Model Matematika Data Panel}

$$
\begin{aligned}
& \text { KMSit }=\beta 0-\beta 1 \text { PDit }-\beta 2 \text { PADit }-\mu \text { it } \\
& \text { PTE it }=\beta 0+\beta 1 \text { PDit }+\beta 2 \text { PADit }+\mu \text { it }
\end{aligned}
$$

dimana :

KMSit $=$ Tingkat kemiskinan untuk kab/kota $\mathrm{i}$ tahun ke $\mathrm{t}$

PTEit $=$ Tingkat pertumbuhan ekonomi untuk 
$\mathrm{kab} /$ kota i tahun ke $\mathrm{t}$

PDit = Pinjaman daerah $\mathrm{kab} / \mathrm{kota} \mathrm{i}$ tahun $\mathrm{ke}$ $\mathrm{t}$

$\mathrm{PAD}$ it $=$ Pendapatan asli daerah $\mathrm{kab} /$ kota $\quad \mathrm{i}$ tahun ke $\mathrm{t}$

$\beta 0, \beta 1 \beta_{2}=$ Parameter regresi

$\mu$ it $\quad=$ Komponen error di waktu t untuk unit crossection $i$

i = data cross section $\mathrm{kab} /$ kota di Jawa Tengah

$\mathrm{t}=$ data time series tahun $2011-2015$

\section{HASIL DAN PEMB AHASAN}

Untuk menentukan model terbaik antara Common Effect Model (CEM) dan Fix Effect Model (FEM) dilakukan dengan menggunakan Uji Chow. Berikut ini adalah hasil dari Uji Chow untuk masing-masing model.

Tabel 2. Hasil Uji Chow Untuk Model Pertama (Pinjaman Daerah, Pendapatan Asli Daerah Terhadap Kemiskinan)

\begin{tabular}{|l|l|l|l|}
\hline Effect Test & Statisti & d.f & Prob \\
\hline Cross-section & 6,4982 & $(20,82)$ & 0,0000 \\
\hline
\end{tabular}

Sumber :DJPK diolah, 2017

Dari tabel 4.1 diketahui nilai p-value untuk cross-section $\mathrm{F} 0,0000<0,05$ artinya $H_{0}$ ditolak. Jadi pada taraf signifikansi 5\%, model fixed effect lebih baik dari pada model common effect

Tabel 3. Hasil Uji Chow Untuk Model Kedua (Pinjaman Daerah, Pendapatan Asli Daerah Terhadap Pertumbuhan Ekonomi)

\begin{tabular}{|l|l|l|l|}
\hline Effect Test & Statistic & d.f & Prob \\
\hline Cross-section & 2,75578 & $(20,82)$ & 0,0007 \\
\hline
\end{tabular}
Sumber: DJPK diolah, 2017

Dari tabel 4.2 diketahui nilai p-value untuk cross-section $\mathrm{F} 0,0000<0,05$ artinya $H_{0}$ ditolak. Jadi pada taraf signifikansi 5\%, model fixed effect lebih baik dari pada model common effect.

Untuk menentukan model terbaik antara Fix Effect Model (FEM) dan Random Effect Model (REM) dilakukan dengan menggunakan Uji
Hausman. Berikut ini adalah hasil dari Uji Hausman untuk masing-masing model.

Tabel 4. Hasil Uji Hausman Model Pertama (Pinjaman Daerah, Pendapatan Asli Daerah Terhadap Kemiskinan )

\begin{tabular}{|l|l|l|l|}
\hline Test Summary & $\begin{array}{l}\text { Chi-Sq. } \\
\text { Statistic }\end{array}$ & $\begin{array}{l}\text { Chi-Sq. } \\
\text { d.f }\end{array}$ & Prob \\
\hline Cross-section & 0,417474 & 2 & 0,8116 \\
\hline
\end{tabular}

Sumber: Data DJPK diolah, 2017

Dari tabel 4.3 diketahui nilai p-value untuk cross-section random $0,8116>0,05$ artinya $H_{0}$ diterima. Jadi pada taraf signifikansi $5 \%$, model random effect lebih baik dari pada model fixed effect.

Tabel 5. Hasil Uji Hausman Model Kedua (Pinjaman Daerah, Pendapatan Asli Daerah Terhadap Pertumbuhan Ekonomi)

\begin{tabular}{|l|l|l|l|}
\hline Test Summary & Chi-Sq. & Chi-Sq. d.f & Prob \\
\hline Cross-section & 0,356251 & 2 & 0,8368 \\
\hline
\end{tabular}

Sumber: Data DJPK diolah, 2017

Dari tabel 4.4 diketahui nilai p-value untuk cross-section random $0,8368>0,05$ artinya $H_{0}$ diterima. Jadi pada taraf signifikansi 5\%, model Random Effect lebih baik dari pada model Fixed effect.

Untuk menentukan model terbaik antara Common Effect Model (CEM) dan Random Effect Model (REM) dilakukan dengan menggunakan Uji Lagrange Multiplier (LM). Berikut ini adalah hasil dari Uji LM yang dilakukan.

Tabel 6. Hasil Uji Lagrange Multiplier(LM) Pinjaman Daerah, Pendapatan Asli Daerah Terhadap Kemiskinan

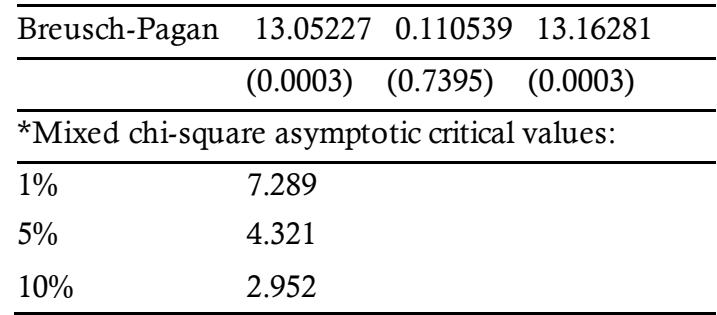

Sumber: Data DJPK diolah, 2017 
Dari tabel 4.5 diketahui nilai prob. Breusch-Pagan $0,0000<0,05$ artinya $H_{0}$ ditolak. Jadi pada taraf signifikansi $5 \%$, model random effect lebih baik dari pada model common effect.

Tabel 7. Hasil Uji Lagrange Multiplier(LM)

Pendapatan Asli Daerah Terhadap Pertumbuhan Ekonomi

Breusch-Pagan 55.12977 11.84244 66.97221 (0.0000) (0.0006) (0.0000)

*Mixed chi-square asymptotic critical values:

$1 \% \quad 7.289$

$5 \% \quad 4.321$

$10 \% \quad 2.952$

Sumber: Data DJPK diolah, 2017

Dari tabel 4.5 diketahui nilai prob. Breusch-Pagan $0,0003<0,05$ artinya $H_{0}$ ditolak. Jadi pada taraf signifikansi 5\%, model random effect lebih baik dari pada model common effect.

\section{Uji Signifikansi Fixed Effect atau Random Effect}

Uji ini dikembangkan oleh Hausman yang dikenal sebagai uji Hausman. Uji Hausman didasarkan pada ide bahwa LSDV di dalam metode fixed effect dan GLS adalah efsiensi sedangkan metode OLS tidak efisien, sedangkan di pihak lain alternatifna adalah OLS efisien dan GLS tidak efisien. Uji Hausman bisa dilakukan dengan berdasarkan perbedaan estimasi keduanya yang tidak berbeda. Jika nilai statistik Hausman lebih besar dari nilai kritisnya maka model yang tepat adalah model fixed effect sedangkan jika nilai statistik Hausman lebih kecil dari nilai kritisnya maka model yang tepat adalah model random effect.

\section{Analisis Regresi Data Panel}

Analisis pengaruh pinjaman daerah, pendapatan asli daerah terhadap kemiskinan dilakukan dengan pengujian estimasi parameter data panel random effect model. Sama halnya dengan analisis pengaruh pinjaman daerah, pendapatan asli daerah terhadap pertumbuhan ekonomi dilakukan dengan estimasi parameter data panel random model. Berdasarkan pengujian yang telah dilakukan, maka model akhir regresi data panel yaitu:

KMS $=296,063-0,00017 *$ PADIt $-4,535 *$ PDt

$+\mu$ it

$\mathrm{PTE}=5,181+1,561 * \mathrm{PADt}+6,4102 * \mathrm{PDt}+$ $\mu$ it

Kedua persamaan regresi tersebut masing-masing dapat diartikan sebagai berikut:

Persamaan 4.1 memiliki nilai konstanta $=$ 296,063. Apabila variabel pinjaman daerah dan pendapatan asli daerah tetap atau konstan, maka kemiskinan akan ada sebesar 296,063.

Koefisien parameter variabel pinjaman daerah pada persamaan 4.1 adalah sebesar Rp.0,00017 yang berarti apabila terjadi peningkatan pinjaman daerah sebesar Rp.1, maka akan mengakibatkan penurunan kemiskinan sebesar Rp.0,00017 dengan asumsi cateris paribus.

Koefisien parameter variabel pendapatan asli daerah pada persamaan 4.1 adalah sebesar Rp.4,535 yang berarti apabila terjadi pendapatan asli daerah sebesar Rp.1, maka akan mengakibatkan penurunan kemiskinan sebesar Rp.4,535 dengan asumsi cateris paribus.

Persamaan 4.2 memiliki nilai konstanta $=$ 5,181, Apabila variabel pinjaman daerah dan pendapatan asli daerah tetap atau konstan, maka pertumbuhan ekonomi akan ada sebesar 5,181 .

Koefisien parameter variabel pinjaman daerah pada persamaan 4.2 adalah sebesar Rp.1,561 yang berarti apabila terjadi peningkatan pinjaman daerah sebesar Rp.1. maka akan mengakibatkan kenaikan pertumbuhan ekonomi sebesar Rp.1,561 dengan asumsi cateris paribus.

Koefisien parameter variabel pinjaman daerah pada persamaan 4.2 adalah sebesar Rp.6,410 yang berarti apabila terjadi peningkatan pendapatan asli daerah sebesar Rp.1, maka akan mengakibatkan kenaikan pertumbuhan ekonomi sebesar Rp.6,410 dengan asumsi cateris paribus. 


\section{Uji Asumsi Klasik}

\section{Uji Normalitas}

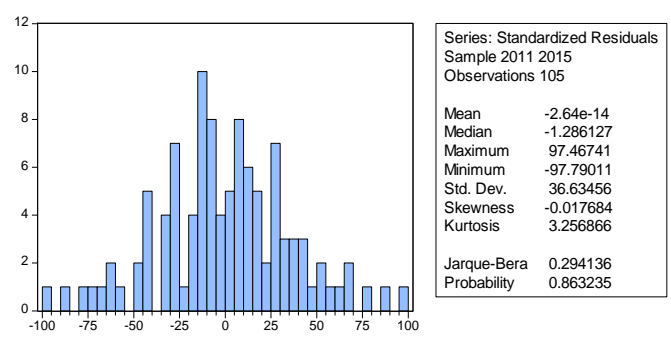

Gambar 2. Hasil Uji Normalitas Model Pertama (Pinjaman Daerah, Pendapatan Asli Daerah Terhadap Kemiskinan)

Sumber: Data DJPK diolah, 2017

Apabila hasil diketahui bahwa nilai probabilitas J-B adalah sebesar $0,863235>$ dari $\alpha$ 0,05 sehingga dapat dinyatakan bahwa data terdistribusi secara normal.

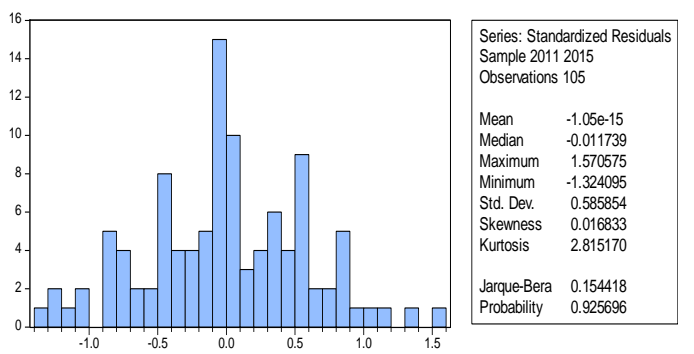

Gambar 3. Hasil Uji Normalitas Model Kedua (Pinjaman Daerah, Pendapatan Asli Daerah Terhadap Kemiskinan dan Pertumbuhan Ekonomi)

Sumber: Data DJPK diolah, 2017

Apabila hasil diketahui bahwa nilai probabilitas J-B adalah sebesar $0,925696>$ dari $\alpha$ 0,05 sehingga dapat dinyatakan bahwa data terdistribusi secara normal.

\section{Uji Multikolenieritas}

Nilai korelasi antar variabel independen kurang dari 0,8 jadi dapat disimpulkan tidak terdapat gejala multikolenieritas pada model regresi.

\section{Pengujian Param eter Regresi}

Model pertama random effect merupakan model terbaik yang digunakan dalam menganalisis pengaruh pinjaman daerah, pendapatan asli daerah terhadap kemiskinan. Sama halnya dengan model kedua menggunakan model random effect yang terbaik untuk menganalisis pengaruh pinjaman daerah, pendapatan asli daerah terhadap pertumbuhan ekonomi.

\section{Koefisien Determinasi $\left(\mathbf{R}^{2}\right)$}

Dari hasil regresi pengaruh pinjaman daerah, pendapatan asli daerah terhadap kemiskinan, diperoleh nilai $\mathrm{R}^{2}$ dengan pendekatan random effect model sebesar 5,82\%, sisanya dijeaskan oleh variabel lain diluar model. Sedangkan untuk hasil regresi pengaruh pinjaman daerah, pendapatan asli daerah terhadap pertumbuhan ekonomi diperoleh $\mathrm{R}^{2}$ dengan pendekatan random effect model sebesar $0,945 \%$, sisanya dijelaskan oleh variabel lain diluar model.

\section{Uji Signifikansi Individu (Uji t)}

Hasil pengujian statistik pada model pertama didapatkan bahwa variabel pinjaman daerah memiliki nilai thitung $=-2.322649>$ nilai ttabel $=1,985$ dengan nilai sig $0,0222<\alpha=5 \%$. Maka $H_{0}$ ditolak, ini menunjukan bahwa variabel pinjaman daerah berpengaruh signifikan terhadap kemiskinan. Pada variabel pendapatan asli daerah memiliki nilai thitung $=-3.147920>$ nilai ttabel $=1,985$ dengan nilai sig $0,0022<\alpha=$ $5 \%$. Maka $H O$ ditolak, ini menunjukan bahwa variabel pendapatan asli daerah berpengaruh signifikan terhadap kemiskinan. Pada pengujian statistik model kedua didapatkan hasil bahwa variabel pinjaman daerah memiliki nilai thitung $=2.782116>$ nilai tabel $=1,985$ dengan nilai sig $0,0064<\alpha=5 \%$. Maka $H_{0}$ ditolak, ini menunjukan bahwa variabel pinjaman daerah berpengaruh signifikan terhadap pertumbuhan ekonomi. Pada variabel pendapatan asli daerah memiliki nilai thitung $=1.289323<$ nilai ttabel $=$ 1,985 dengan nilai sig $0,2002>\alpha=5 \%$. Maka $H_{0}$ diterima, ini menunjukan bahwa variabel pendapatan asli daerah tidak berpengaruh signifikan terhadap pertumbuhan ekonomi. 


\section{Pengaruh Pinjaman Daerah Terhadap Kemiskinan}

Menurut pasal 1 angka 9 PP 54/2005. Daerah mempergunakan dana tersebut salah satunya untuk menanggulangi angka kemiskinan, melalui pinjaman daerah maka daerah memperoleh dana untuk membangun infrastruktur dan fasilitas penunjang bagi masyarakat sehingga daerah memperoleh pendapatan asli daerah yang kemudian berputar kembali pada pembangunan fasilitas yang dibutuhkan dan banyak dibutuhkan tenaga kerja. Sehingga dalam hal ini akan mengurangi angka kemiskinan.

\section{Pengaruh Pendapatan Asli Daerah Terhadap Kemiskinan}

Hasil penelitian variabel pendapatan asli daerah daerah terhadap kemiskinan adalah negatif signifikan dengan nilai koefisien 0,000176 dan probabilitas $<0,05$. Besarnya pengaruh itu dapat dijelaskan jika terjadi kenaikan pendapatan asli daerah sebesar Rp.1 akan menurunkan kemiskinan sebesar Rp.0,000176 dengan asumsi cateris paribus. Hal ini menunjukkan bahwa variabel pendapatan asli daerah memiliki pengaruh terhadap kemiskinan. Jadi dapat disimpulkan bahwa hipotesis yang menyatakan terdapat pengaruh pendapatan asli daerah terhadap kemiskinan diterima.

\section{Pengaruh Pinjaman Daerah Terhadap Pertumbuhan Ekonomi}

Penelitian ini sesuai dengan hasil penelitian Wei Te (1995) dalam Mulyono (2007) menyatakan bahwa kota turis memiliki pertumbuhan ekonomi yang lebih tinggi, akibatnya mereka harus memenuhi demand untuk fasilitas kota, seperti infrastruktur ekonomi dan layanan publik lainnya. Suatu daerah dengan tingkat pertumbuhan ekonomi yang cenderung berkembang maka akan berakibat pada tingginya permintaan akan barang dan jasa oleh masyarakat. Dengan demikian, pemerintah harus meningkatkan infrastruktur ekonomi dan pelayanan publik yang lebih baik dan kondisi ini akan berdampak pada tingginya pengeluaran, untuk menutupi kekurangan dana maka pemerintah daerah melakukan pinjaman.

\section{Pengaruh Pendapatan Asli Daerah Terhadap Pertumbuhan Ekonomi}

Hasil penelitian variabel pendapatan asli daerah terhadap pertumbuhan ekonomi adalah tidak signifikan dengan nilai koefisien 1,5606 dan probabilitas $>0,05$. Hal ini menunjukkan bahwa variabel pendapatan asli daerah tidak memiliki pengaruh terhadap pertumbuhan ekonomi. Penelitian ini bertentangan oleh hasil penelitian Putri (2015) Pendapatan asli daerah merupakan salah satu indikator dalam mengukur pertumbuhan ekonomi suatu daerah. Semakin besar pendapatan asli daerah maka akan meningkatkan pertumbuhan ekonomi, apabila suatu daerah memiliki pendapatan asli daerah yang rendah maka akan menurunkan pertumbuhan ekonomi. Secara teori pendapatan asli daerah didapat dari pajak daerah,retibusi daerah, hasil perusahaan milik daerah, dan lainlain pendapatan daerah yang sah.

\section{SIMPULAN}

Berdasarkan hasil penelitian dan pembahasan dapat diperoleh simpulan bahwa pinjaman daerah berpengaruh signifikan terhadap kemiskinan, pendapatan asli daerah berpengaruh signifikan terhadap kemiskinan. Hal ini menunjukkan bahwa peningkatan atau penurunan pinjaman daerah dapat menjadi salah satu yang mempengaruhi kemiskinan, pinjaman daerah berpengaruh signifikan terhadap pertumbuhan ekonomi. Hal ini menunjukkan bahwa peningkatan atau penurunan pinjaman daerah dapat menjadi salah satu yang mempengaruhi pertumbuhan ekonomi, tidak terdapat pengaruh pendapatan asli daerah terhadap pertumbuhan ekonomi..

\section{DAFTAR PUSTAKA}

LPEM-UI. 2004. Bahan Ajar Pendidikan dan Pelatihan Pengelolaan Hibah dan Pinjaman tahun 2004. Jakarta: LPEM-UI.

Mulyono, Imam.2007. Faktor-faktor Yang Mempengaruhi Pinjaman Daerah. Jurnal 
Akuntansi dan Teknologi Informasi. Vol.6. No.2. November 2007.

Peraturan Pemerintah RI Nomor: 107 Tahun 2000 tentang Pinjaman Daerah. Dalam ketentuan umum pasal 1.

Santosa, Rokhedi. 2003. Analisis Pinjaman Sebagai Potensi Pembiayaan Pembangunan Daerah :Studi Kasus Daerah Istimewa Yogyakarta. Jurnal Ekonomi Pembangunan. Vol 8. No.2 Desember 2003.

Putri ,Zuwesty Eka.2015. Analisis Pengaruh Pendapatan Asli Daerah (Pad), Dana Alokasi Umum (Dau) Dan Inflasi Terhadap
Pertumbuhan Ekonomi Di Kabupaten/Kota Provinsi Jawa Tengah .vol. 5, No.2

Undang-undang Nomor 107 Tahun 2000 http://www.bi.go.id/id/publikasi/kajianekonomi-regional/jateng/Pages/Kajian Ekonomi-dan-Keuangan-Regional-

Undang-undang Nomor 33 Tahun 2004 tentang Perimbangan Keuangan Antara Pusat dan Daerah Pasal 1 angka 18 bahwa " Pendapatan asli daerah, selanjutnya disebut PAD adalah pendapatan yang diperoleh daerah yang dipungut berdasarkan peraturan daerah sesauidengan peraturan perundangundang. 